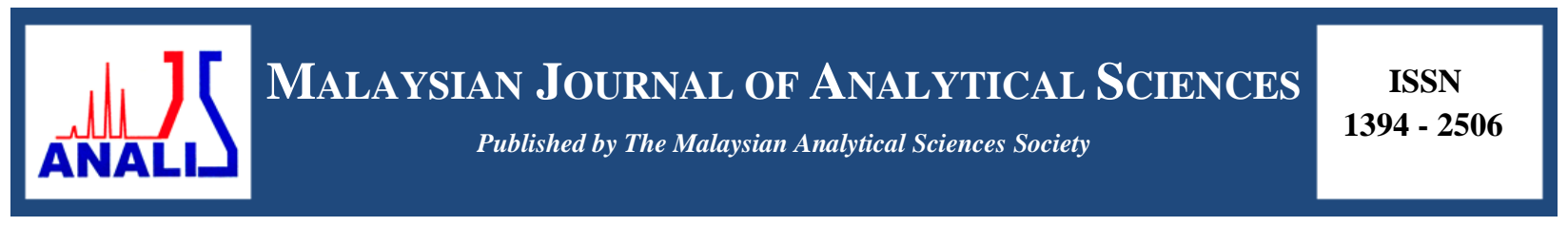

\title{
EFFECT OF TEMPERATURE ON THE CATALYTIC ACTIVITY OF NEW SYMMETRICAL TETRADENTATE PALLADIUM(II) SCHIFF BASE COMPLEXES IN COPPER-FREE SONOGASHIRA REACTION
}

\author{
(Kesan Suhu Terhadap Aktiviti Pemangkinan Kompleks Baru Paladium(II) Tetradentat Bes \\ Schiff Bersimetri dalam Tindak Balas Sonogashira Tanpa Kuprum) \\ Shahrul Nizam Ahmad ${ }^{1}$, Hadariah Bahron ${ }^{1}$, Amalina Mohd Tajuddin ${ }^{2}$ \\ ${ }^{I}$ Faculty of Applied Sciences, \\ Universiti Teknologi MARA, 40450 Shah Alam, Selangor, Malaysia \\ ${ }^{2}$ Atta-ur-Rahman Institute for Natural Product Discovery, \\ Level 9, Building FF3, UiTM Selangor, Kampus Puncak Alam, Bandar Puncak Alam, Selangor, Malaysia \\ *Corresponding author: shahrulnizam85@gmail.com
}

Received: 29 August 2018; Accepted: 18 February 2019

\begin{abstract}
This paper reports the synthesis of two tetradentate Schiff bases namely 2,2'-(((2,2-dimethylpropane-1,3-diyl) bis(azanylylidene))bis(methanylylidene))bis(4-methoxylphenol), LM, and 2,2'-(((2,2-dimethylpropane-1,3-diyl)bis (azanylylidene))bis(methanylylidene))bis(4-nitrophenol), LN. The Schiff bases were reacted with palladium(II) acetate in 1:1 molar ratio yielding two palladium(II) complexes, PdLN and PdLM. The compounds were characterized through elemental analysis, infrared spectroscopy, ${ }^{1} \mathrm{H}$ and ${ }^{13} \mathrm{C}$ Nuclear Magnetic Resonance (NMR), magnetic susceptibility, molar conductivity and melting point. Complexation was indicated to have occurred by the shifting of the characteristic $v(C=N), v(C-O)$ and $\delta(\mathrm{HC}=\mathrm{N})$ peaks. This was supported by appearance of new peaks of $v(\mathrm{M}-\mathrm{N})$ and $v(\mathrm{M}-\mathrm{O})$ as well as disappearance of $\delta(\mathrm{O}-\mathrm{H})$ peak on the IR and ${ }^{1} \mathrm{H}$ NMR spectra of the palladium(II) complexes. The diamagnetic and non-electrolytic nature of the complexes suggested square planar $d^{8}$ palladium(II) geometry and absence of counter ions, respectively. The catalytic activity of the palladium(II) complexes was investigated for copper-free Sonogashira reaction between iodobenzene and phenylacetylene in dimethylsulfoxide (DMSO) at $80{ }^{\circ} \mathrm{C}, 100^{\circ} \mathrm{C}$ and $140{ }^{\circ} \mathrm{C}$. The conversion of iodobenzene at $12 \mathrm{~h}$ reaction time was monitored by GC-FID. At $100{ }^{\circ} \mathrm{C}$, the most active catalyst was PdLN, indicating that the electron withdrawing substituent $-\mathrm{NO}_{2}$, has the ability to enhance catalytic properties of the complexes. At $140{ }^{\circ} \mathrm{C}$, both palladium(II) complexes successfully converted $100 \%$ of iodobenzene.
\end{abstract}

Keywords: Schiff base, palladium(II) complexes, Sonogashira, temperature change

\begin{abstract}
Abstrak
Kertas kajian ini melaporkan sintesis dua bes Schiff tetradentat iaitu 2,2'-(((2,2-dimetilpropana-1,3-diyl)bis(azanililidena))bis(methanililidena))bis(4-metoksilfenol), LM dan 2,2'-(((2,2-dimetilpropana-1,3-diyl)bis(azanililidena))bis(methanililidena))bis(4-nitrofenol), LN. Bes Schiff tersebut telah ditindakbalaskan dengan palladium(II) asetat dengan nisbah mol 1:1, menghasilkan dua kompleks palladium(II), iaitu PdLN dan PdLM. Sebatian telah dicirikan melalui analisis unsur, spektroskopi inframerah (IM), Resonans Magnetik Nuklear (RMN) ${ }^{1} \mathrm{H}$ dan ${ }^{13} \mathrm{C}$, kerentanan magnetik, kekonduksian molar dan takat lebur. Pengkompleksan ditunjukkan telah berlaku dengan penganjakan puncak $v(\mathrm{C}=\mathrm{N}), v(\mathrm{C}-\mathrm{O})$ dan $\delta(\mathrm{HC}=\mathrm{N})$. Ia dikukuhkan lagi dengan munculnya puncak baru $v(\mathrm{M}-\mathrm{N})$ dan $v(\mathrm{M}-\mathrm{O})$ dan hilangnya puncak $\delta(\mathrm{O}-\mathrm{H})$ pada spektrum IM dan ${ }^{1} \mathrm{H}$ RMN kompleks paladium(II). Sifat diamagnetik dan bukan elektrolit komplek mencadangkan geometri satah segiempat sama $d^{8}$ paladium(II) dan ketiadaan ion kaunter, masing-masing. Aktiviti pemangkinan komplek paladium(II) dikaji bagi tindakbalas Sonogashira tanpa kuprum antara iodobenzena dan fenilasetilena dalam dimetilsulfoksida (DMSO) pada $80{ }^{\circ} \mathrm{C}, 100{ }^{\circ} \mathrm{C}$ dan $140{ }^{\circ} \mathrm{C}$. Peratusan
\end{abstract}




\section{Shahrul Nizam et al: EFFECT OF TEMPERATURE ON THE CATALYTIC ACTIVITY OF NEW SYMMETRICAL TETRADENTATE PALLADIUM(II) SCHIFF BASE COMPLEXES IN COPPER-FREE SONOGASHIRA REACTION}

penukaran iodobenzena pada jam ke-12 tindak balas dipantau dengan GC-FID. Pada $100{ }^{\circ} \mathrm{C}$, pemangkin yang paling aktif adalah PdLN, menandakan bahawa kumpulan tertukar ganti penarik elektron, $-\mathrm{NO}_{2}$, boleh meningkatkan sifat pemangkinan kompleks. Pada $140{ }^{\circ} \mathrm{C}$, kedua-dua kompleks paladium(II) berjaya menukarkan $100 \%$ iodobenzena.

Kata kunci: Bes Schiff, kompleks paladium(II), Sonogashira, perubahan suhu

\section{Introduction}

A Schiff base is typically formed through condensation reaction between a primary amine with an aldehyde or a ketone with removal of a water molecule [1]. It is also known as imine or azomethine and dubbed as a nitrogen analogue of an aldehyde or ketone, in which the carbonyl group $(\mathrm{C}=\mathrm{O})$ is replaced by an imine $(\mathrm{C}=\mathrm{N})$ [2]. Schiff bases and their transition metal complexes have been reported to have wide applications such as anticancer, antibacterial, antiviral [3], corrosion inhibition [4] and catalysis [5]. Schiff base metal complexes have been extensively investigated as homogeneous and heterogeneous catalysts in various chemical reactions including carbon-carbon coupling reactions [5]. They are reported to have outstanding catalytic activities and can withstand high temperatures of more than $100^{\circ} \mathrm{C}$, functioning effectively even in the presence of moisture [5].

Sonogashira reaction is an $\mathrm{sp}^{2}$-sp carbon-carbon bond formation, usually between aryl or vinyl halide and terminal acetylene [6]. It has received enormous attention due to its wide application in synthesis of natural products, biologically active molecules, heterocycles, molecular electronics, dendrimers and conjugated polymers or nanostructures [6]. The original reaction has been modified since its discovery in 1975 by varying the palladium environment, base, catalyst loading, solvent, additive and temperature [7]. The movement towards copper-free Sonogashira reaction is increasing over the years as the application of copper salts as co-catalysts has experimentally proven to be the culprit of Glaser-type oxidative dimerization of the alkyne substrate [8] that caused contamination of the desired alkyne product.

The application of phosphine-based complexes as catalysts is common to enhance the performance of C-C formation reactions. However, these complexes have certain demerits in that they are sensitive towards air and moisture, relatively costly and environmentally harmful [9]. Nitrogen-based complexes like Schiff bases are believed to be good candidates to substitute phosphine-based complexes as the former are air- and moisture-stable, relatively cheaper and environmentally benign. Furthermore, Schiff bases are able to stabilize many different metals in various oxidation states, enhancing the performance of metals [10]. These advantages have popularised Schiff bases metal complexes in recent catalytic studies. Although the application of Schiff base complexes, for example, salen complexes in Heck and Suzuki coupling reaction is exhaustive, its application in copper-free Sonogashira reactions is still limited.

Much work has been devoted to optimize the reaction conditions for Sonogashira coupling reactions in which the optimum temperatures, catalyst loadings, solvents and bases were explored. Reaction conditions typically vary from one reaction to another depending on the types of substrates and catalysts used. An optimum temperature can be as low as room temperature $[11,12]$ as high as $140{ }^{\circ} \mathrm{C}[13]$. The search for optimum reaction temperature is significant as inappropriate supply of heat to the reaction may inhibit the reaction and impede catalysts from performing effectively. Additionally, finding the optimum temperature is important for cost effectiveness. Optimization is essential particularly when palladium complexes are employed as catalysts because palladium black may occur if the reaction temperature is too high, causing deactivation of the catalytic sites. On the other hand, if the reaction temperature is too low, the percent conversion of reactants may be low.

This work reports the synthesis of two new complexes of palladium(II) with symmetrical tetradentate Schiff base ligands bearing ONNO donor atoms. The catalytic performance of the complexes was appraised on copper-free Sonogashira reaction between iodobenzene and phenylacetylene in dimethylsulfoxide (DMSO) for 12 hours at different temperatures. The findings reported herein are beneficial in understanding the catalytic performance of Schiff base complexes in homogenous Sonogashira reaction system with the absence of the conventional cocatalyst, copper(I) salt. 


\section{General}

\section{Materials and Methods}

Ethanol, acetonitrile, 2,2-dimethyl-1,3-propanediamine, 5-methoxysalicyladehyde and 5-nitrosalicylaldehyde purchased from commercial suppliers were used without prior purification. The micro-analytical data $(\mathrm{C}, \mathrm{H}$, and $\mathrm{N})$ of all ligands and complexes were obtained from Thermo Scientific Flash 2000 Elemental Analyser. Melting points were determined on Stuart SMP10. Perkin-Elmer Spectrum One FTIR spectrometer using KBr pellets was employed to record infrared (IR) spectra of ligands and complexes between $450-4000 \mathrm{~cm}^{-1} .{ }^{1} \mathrm{H}$ and ${ }^{13} \mathrm{C}$ NMR spectra were recorded on a Bruker Varian $-600 \mathrm{MHz}$ spectrometer as $\mathrm{CDCl}_{3}$ solutions and expressed in parts per million $(\delta, \mathrm{ppm})$. The magnetic susceptibility of the palladium(II) complexes was measured using Sherwood Auto Magnetic Susceptibility Balance. The molar conductivity of the complexes was determined using Mettler Toledo Inlab 730 conductivity meter in $10^{-3} \mathrm{M}$ of DMSO solution. The percent conversion of iodobenzene was monitored using Gas Chromatography-Flame Ionization Detection (GC-FID) model Agilent 6890N. The syntheses of ligands and complexes are presented in Scheme 1.

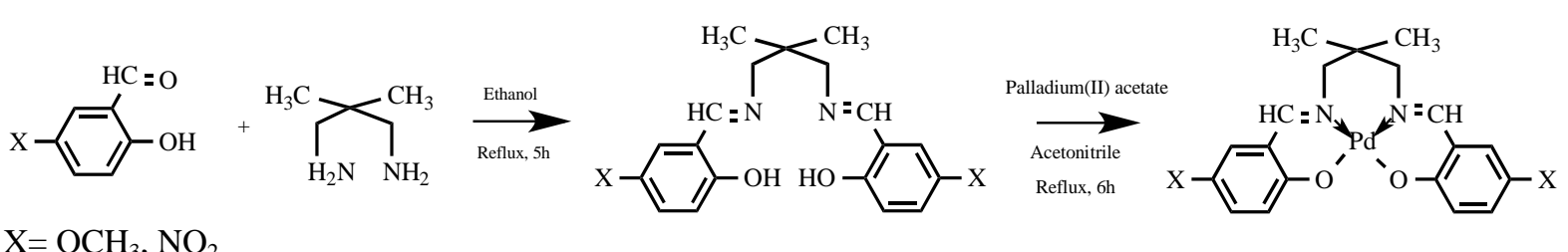

Scheme 1. The synthesis of LM and LN and their palladium(II) complexes

\section{Synthesis of LM and LN ligands}

A hot solution of 2,2-dimethlyl-1,3-propanediamine $\mathrm{C}_{5} \mathrm{H}_{14} \mathrm{~N}_{2}(1 \mathrm{mmol}, 0.1022 \mathrm{~g})$ in absolute ethanol $(10 \mathrm{~mL})$ was added to a stirred solution of 5-methoxysalicylaldehyde $\mathrm{C}_{8} \mathrm{H}_{8} \mathrm{O}_{3}(2 \mathrm{mmol}, 0.3044 \mathrm{~g})$ or 5-nitrosalicylaldehyde $\mathrm{C}_{7} \mathrm{H}_{5} \mathrm{NO}_{4}(2 \mathrm{mmol}, 0.3342 \mathrm{~g})$ in absolute ethanol $(5 \mathrm{~mL})$ for $\mathrm{LM}$ and $\mathrm{LN}$, respectively. The solution was refluxed for 5 hours, cooled and chilled overnight. The yellow solid obtained was filtered off, washed with cold ethanol and air dried.

\section{Synthesis of PdLM and PdLN complexes}

Palladium(II) acetate $(1 \mathrm{mmol}, 0.2248 \mathrm{~g})$ was dissolved in $10 \mathrm{~mL}$ of dry acetonitrile in a round-bottomed flask. The ligand $\mathrm{LN}$ ( $1 \mathrm{mmol}, 0.4004 \mathrm{~g}$ ) or $\mathrm{LM} \mathrm{C}_{21} \mathrm{H}_{26} \mathrm{~N}_{2} \mathrm{O}_{4}(1 \mathrm{mmol}, 0.3705 \mathrm{~g})$ was also dissolved separately in $10 \mathrm{~mL}$ of dry acetonitrile, then added dropwise into the metal solution. The mixture was refluxed for 6 hours. The orange (PdLM) or yellow (PdLN) solid obtained was washed with $5 \mathrm{~mL}$ of cold acetonitrile, filtered off and air-dried.

\section{Copper-free Sonogashira reaction}

A round-bottomed flask was charged with iodobenzene $(1.0 \mathrm{mmol})$, phenylacetylene $(1.5 \mathrm{mmol})$, palladium(II) Schiff base complex $(0.02 \mathrm{mmol})$ and $\mathrm{KOH}(2.0 \mathrm{mmol})$, with stirring under aerobic condition in $7 \mathrm{~mL}$ of DMSO (Scheme 2). The mixture was heated at $80{ }^{\circ} \mathrm{C}, 100{ }^{\circ} \mathrm{C}$ and $140{ }^{\circ} \mathrm{C}$ for 12 hours and monitored every 3 hours by Gas Chromatography-Flame Ionization Detection (GC-FID) to determine the percentage conversion of iodobenzene, calculated using equation 1 :

$$
\% \text { Conversion }=\left(\mathrm{A}_{\text {int }}-\mathrm{A}_{\text {final }}\right) / \mathrm{A}_{\text {int }}
$$

where $\mathrm{A}_{\text {int }}$ is peak area of iodobenzene before reaction and $\mathrm{A}_{\text {final }}$ is peak area of iodobenzene after reaction. 


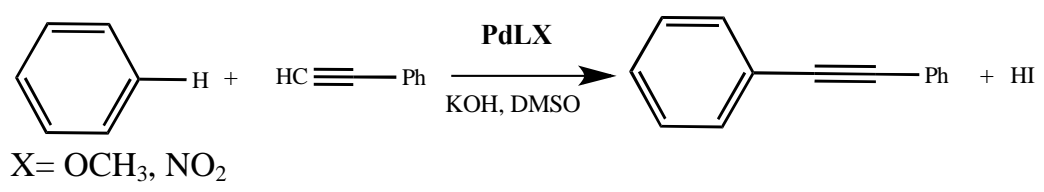

Scheme 2. Copper-free Sonogashira reaction

\section{Elemental analysis and melting point}

\section{Results and Discussion}

The experimental percentages of elements $\mathrm{C}, \mathrm{H}$ and $\mathrm{N}$ of the compounds are presented in Table 1 and are in close accord with the theoretical values. Based on the elemental analysis results, the structures of the ligands and palladium(II) complexes are as those predicted in Scheme 1. The temperature ranges for melting points listed in Table 1 represent the points at which the compounds started to melt and completely molten [14]. The melting points of the complexes are higher than their parent ligands, likely because of the increased molecular sizes and the presence of strong ionic and dative covalent bonds.

Table 1. Physicochemical properties of LM, LN and their respective palladium(II) complexes

\begin{tabular}{|c|c|c|c|c|c|c|c|}
\hline \multirow{2}{*}{ Compound } & \multirow{2}{*}{ Color } & \multirow{2}{*}{$\begin{array}{c}\text { Percent } \\
\text { Yield (\%) }\end{array}$} & \multirow{2}{*}{$\begin{array}{l}\text { Chemical } \\
\text { Formula }\end{array}$} & \multirow{2}{*}{$\begin{array}{c}\text { Melting } \\
\text { Point }\left({ }^{\circ} \mathbf{C}\right)\end{array}$} & \multicolumn{3}{|c|}{ Elemental Analysis \% (Calculated) } \\
\hline & & & & & $\mathbf{C}$ & $\mathbf{H}$ & $\mathbf{N}$ \\
\hline LM & Yellow & 92.0 & $\mathrm{C}_{21} \mathrm{H}_{26} \mathrm{~N}_{2} \mathrm{O}_{4}$ & $101-105$ & $\begin{array}{c}68.09 \\
(67.91)\end{array}$ & $\begin{array}{c}7.07 \\
(7.94)\end{array}$ & $\begin{array}{c}7.56 \\
(7.54)\end{array}$ \\
\hline $\mathrm{LN}$ & Yellow & 91.0 & $\mathrm{C}_{19} \mathrm{H}_{2}{ }_{0} \mathrm{~N}_{4} \mathrm{O}_{6}$ & $210-212$ & $\begin{array}{c}57.00 \\
(55.56)\end{array}$ & $\begin{array}{c}5.04 \\
(4.97)\end{array}$ & $\begin{array}{c}13.99 \\
(14.64)\end{array}$ \\
\hline PdLM & Orange & 67.3 & $\mathrm{C}_{21} \mathrm{H}_{24} \mathrm{~N}_{2} \mathrm{O}_{4} \mathrm{Pd}$ & $200-205$ & $\begin{array}{c}53.12 \\
(51.63)\end{array}$ & $\begin{array}{c}5.09 \\
(5.47)\end{array}$ & $\begin{array}{c}5.90 \\
(6.19)\end{array}$ \\
\hline PdLN & Yellow & 90.5 & $\mathrm{C}_{19} \mathrm{H}_{18} \mathrm{~N}_{4} \mathrm{O}_{6} \mathrm{Pd}$ & $>300$ & $\begin{array}{c}45.21 \\
(44.03)\end{array}$ & $\begin{array}{c}3.59 \\
(3.56)\end{array}$ & $\begin{array}{c}11.10 \\
(12.48)\end{array}$ \\
\hline
\end{tabular}

\section{Infrared spectroscopy}

The IR spectra of LM, LN and their Pd(II) complexes are presented in Figure 1 and significant peaks listed in Table 2. The $v(\mathrm{C}=\mathrm{N})$ peaks of ligands appeared in the range of $1611-1638 \mathrm{~cm}^{-1}$, shifted by $10-31 \mathrm{~cm}^{-1}$ to lower frequencies of $1607-16201 \mathrm{~cm}^{-1}$ in the $\mathrm{Pd}(\mathrm{II})$ complexes, indicating that the $\mathrm{C}=\mathrm{N}$ experienced a lowering in bond strength upon complexation through azomethine nitrogen. The lone pair of electrons on $\mathrm{N}$ was donated to the metal center in a Lewis acid-base interaction, resulting in the reduction of $\pi$-electron density on $\mathrm{C}=\mathrm{N}$, hence weakening it. The shifting of the C-O band from $1034 \mathrm{~cm}^{-1}$ in LM to $1041 \mathrm{~cm}^{-1}$ in PdLM, and from $1097 \mathrm{~cm}^{-1}$ in LN to 1100 $\mathrm{cm}^{-1}$ in PdLN, indicated coordination between ligands and palladium(II) through phenolic oxygen. A couple of new bands appeared in the range of $468-480 \mathrm{~cm}^{-1}$ and $540-571 \mathrm{~cm}^{-1}$ for palladium(II) complexes assignable to Pd-O and Pd-N, respectively, assenting with the values reported by Bahron et al. [16]. Other significant peaks that deserve some attention are the $\mathrm{C}=\mathrm{C}$ stretch $\left(1544-1592 \mathrm{~cm}^{-1}\right)$, and $\mathrm{C}-\mathrm{H} \mathrm{sp}{ }^{2}$ stretch $\left(3008-3069 \mathrm{~cm}^{-1}\right)$, indicating the presence of benzene rings in the structure. The appearance of C- $\mathrm{H} \mathrm{sp}^{3}$ stretch in the range of $2943-2967 \mathrm{~cm}^{-1}$ are indicators that methyl $\left(\mathrm{CH}_{3}\right)$ groups are part of the chemical structures. 


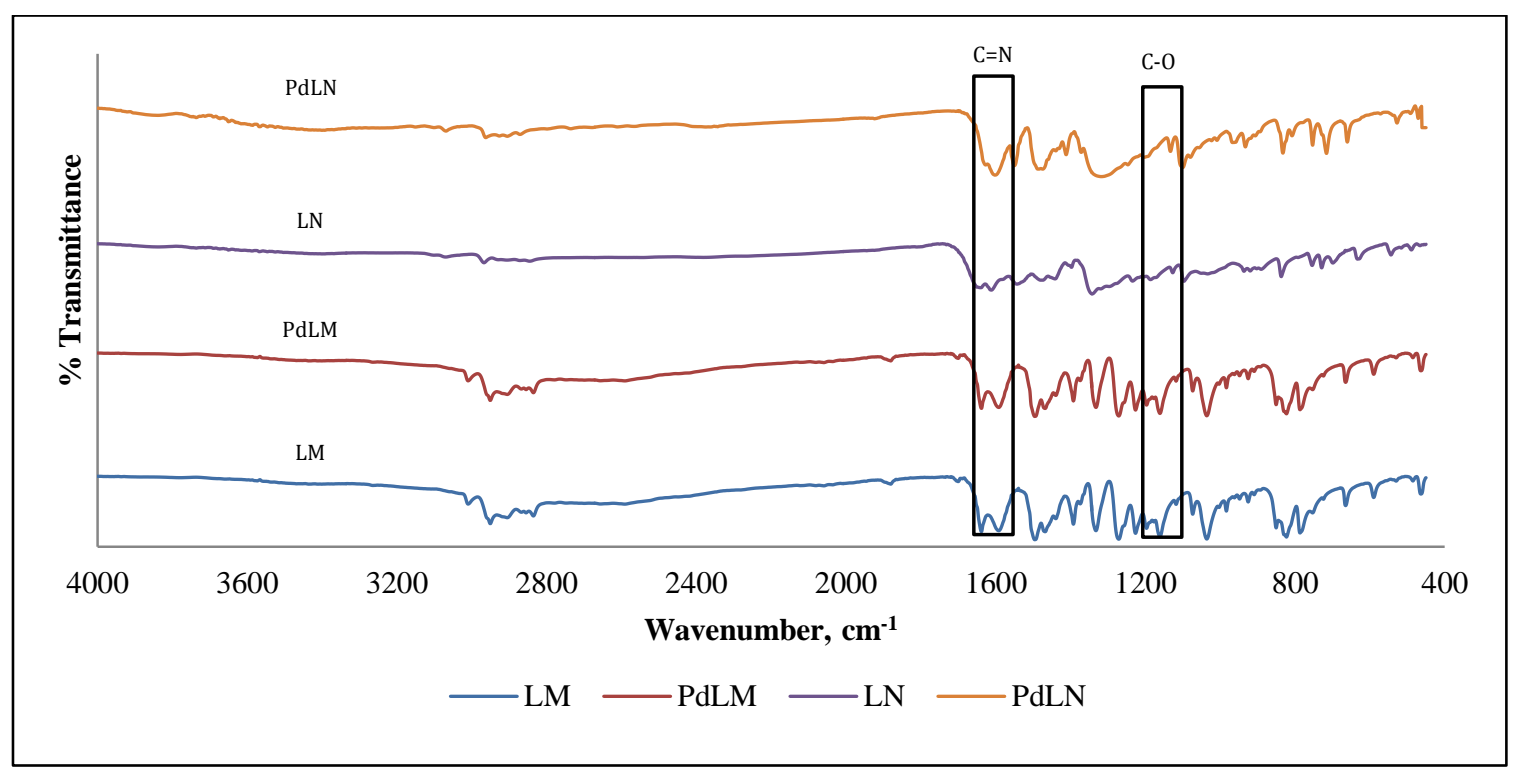

Figure 1. FTIR spectra of LM, LN and their Pd(II) complexes

Table 2. Selected infrared spectral data of LM, LN and their respective palladium(II) complexes

\begin{tabular}{|c|c|c|c|c|}
\hline & \multicolumn{4}{|c|}{ Frequency, $v\left(\mathrm{~cm}^{-1}\right)$} \\
\hline & $\mathbf{L M}$ & PdLM & $\mathbf{L N}$ & PdLN \\
\hline $\mathrm{C}=\mathrm{N}$ & $1638(s)$ & $1607(s)$ & $1611(s)$ & $1601(s)$ \\
\hline $\mathrm{C}-\mathrm{O}$ & $1034(s)$ & $1041(w)$ & $1097(m)$ & $1100(m)$ \\
\hline Pd-N & - & $571(w)$ & - & $540(w)$ \\
\hline $\mathrm{Pd}-\mathrm{O}$ & - & $468(w)$ & - & $480(w)$ \\
\hline $\mathrm{C}=\mathrm{C}$ stretch & $1592(s)$ & $1541(s)$ & $1544(m)$ & $1550(m)$ \\
\hline C-H sp ${ }^{2}$ stretch & $3008(w)$ & $3014(w)$ & $3069(w)$ & $3068(w)$ \\
\hline $\mathrm{C}-\mathrm{H} \mathrm{sp}{ }^{3}$ stretch & $2951(w)$ & $2943(w)$ & $2967(w)$ & $2963(w)$ \\
\hline $\mathrm{C}-\mathrm{H} \mathrm{sp} \mathrm{s}^{3}$ bend & $1363(s)$ & $1365(w)$ & $1397(w)$ & $1371(w)$ \\
\hline $\mathrm{CH}_{2}$ bend & $1492(s)$ & $1490(w)$ & $1441(w)$ & $1411(w)$ \\
\hline
\end{tabular}

br: broad, s: strong, m: medium, w: weak

\section{Nuclear magnetic resonance spectroscopy}

Table 3 presents ${ }^{1} \mathrm{H}$ NMR data of LM and PdLM. The spectra of LN and PdLN were not obtained due to their insolubility. The $\mathrm{OH}$ signals of LM appeared as a broad peak at the downfield region of $13.10 \mathrm{ppm}$ in LM, indicating the existance of hydrogen bondings [15]. Due to the electronegative oxygen that withdrew electron density from the phenolic proton, the latter was highly deshielded from the magnetic field, causing the chemical shift to appear at the downfield region. The absence of the phenolic proton peak in the spectrum of PdLM shows that the coordination was established between phenolic oxygen and metal center through deprotonation of the hydroxyl group. The chemical shifts of aromatic hydrogen appeared as multiplets at $6.79-6.97 \mathrm{ppm}$. The values of coupling constants as tabulated in Table 3 are in the range of 1-3 Hz and 6-9 Hz, suggesting the existence of meta and ortho aromatic protons, respectively. This is in agreement with the chemical shifts reported by Amalina et al. [17]. These hydrogens were deshielded due to diamagnetic anisotropy contributed by circulating $\pi$ electrons in the aromatic rings. The number of hydrogens was in concordance with the proposed structure. An evidence of 


\section{Shahrul Nizam et al: EFFECT OF TEMPERATURE ON THE CATALYTIC ACTIVITY OF NEW SYMMETRICAL TETRADENTATE PALLADIUM(II) SCHIFF BASE COMPLEXES IN COPPER-FREE SONOGASHIRA REACTION}

complexation can be seen through the shifting of $\delta(\mathrm{HC}=\mathrm{N})$ singlet from $8.32 \mathrm{ppm}$ in free LM to $7.56 \mathrm{ppm}$ in PdLM, suggesting a shielding of the azomethine proton by the $\mathrm{Pd}(\mathrm{II})$ center. The presence of methyl group, $\mathrm{CH}_{3}, \mathrm{CH}_{2}$ and $\mathrm{OCH}_{3}$ protons was detected as singlets at $1.10,3.47$ and $3.80 \mathrm{ppm}$ in LM, respectively. These chemical shifts experienced very little or no shifting at all upon complexation, signifying their non-involvement.

Table 3. ${ }^{1} \mathrm{H}$ NMR spectral data of LM and PdLM

\begin{tabular}{lcc}
\hline & \multicolumn{2}{c}{ Chemical Shift, $\boldsymbol{\delta}(\mathbf{p p m})$} \\
\cline { 2 - 3 } & $13.10(\mathrm{~s}, 1 \mathrm{H})$ & PdLM \\
\hline $\mathrm{OH}$ & $8.32(\mathrm{~s}, 1 \mathrm{H})$ & - \\
$\mathrm{HC}=\mathrm{N}$ & $1.10(\mathrm{~s}, 2 \mathrm{H})$ & $7.52(\mathrm{~s}, 1 \mathrm{H})$ \\
$\mathrm{CH}_{3}$ & $3.47(\mathrm{~s}, 2 \mathrm{H})$ & $1.10(\mathrm{~s}, 3 \mathrm{H})$ \\
$\mathrm{CH}_{2}$ & $3.80(\mathrm{~s}, 3 \mathrm{H})$ & $3.50(\mathrm{~s}, 2 \mathrm{H})$ \\
$\mathrm{OCH}_{3}$ & & $3.80(\mathrm{~s}, 3 \mathrm{H})$ \\
Aromatic proton $(A r-\mathrm{H})$ & $6.79-6.97(\mathrm{~m}, \mathrm{~J}=1-3,6-9 \mathrm{~Hz}, 3 \mathrm{H})$ & $6.96-7.10(\mathrm{~m}, J=1-3,6-9 \mathrm{~Hz}, 3 \mathrm{H})$ \\
\hline s: singlet, m: multiplet & &
\end{tabular}

Table 4 presents ${ }^{13} \mathrm{C}$ NMR data of LM. The peak of carbon bonded to oxygen of the phenolic group, $\delta(\mathrm{C}-\mathrm{OH})$ appeared at $152.04 \mathrm{ppm}$, further upfield than the azomethine carbon which was detected at $165.45 \mathrm{ppm}$, demonstrating the bigger shielding effect of $\mathrm{O}$ than $\mathrm{N}$. The signal for $\mathrm{CH}_{3}, \mathrm{OCH}_{3}$ and $\mathrm{CH}_{2}$ were found at 24.44, 55.95 and $68.29 \mathrm{ppm}$, respectively. Aromatic carbons were detected in the range of 114.83-119.41 ppm. There are no ${ }^{13} \mathrm{C}$ NMR spectra obtained for PdLM, LN and PdLN owing to poor solubility of the compounds.

Table 4. ${ }^{13}$ C NMR spectral data of LM

\begin{tabular}{lc}
\hline & Chemical shift, $\boldsymbol{\delta}(\mathbf{p p m})$ \\
\cline { 2 - 2 } & $\mathbf{L M}$ \\
\hline $\mathrm{C}-\mathrm{OH}$ & 152.04 \\
$\mathrm{C}=\mathrm{N}$ & 165.45 \\
$\mathrm{CH}_{3}$ & 24.44 \\
$\mathrm{OCH}_{3}$ & 55.95 \\
$\mathrm{CH}_{2}$ & 68.29 \\
Aromatic carbon (Ar-C) & $114.83-119.41$ \\
\hline
\end{tabular}

\section{Magnetic susceptibility and molar conductivity}

All complexes revealed 0 effective magnetic moment, $\mu_{\text {eff }}$, indicating the absence of unpaired electrons, corresponding to the diamagnetic square planar $d^{8}$ palladium(II) system. The complexes showed molar conductivity of $0 \lambda_{\mathrm{m}} / \Omega^{-1} \mathrm{~cm}^{2} \mathrm{~mol}^{-1}$ suggesting their non-electrolytic nature, with absence of any counter ions.

\section{Catalytic activity of palladium(II) Schiff base complexes for copper-free Sonogashira reaction}

PdLM and PdLN were screened as catalysts in copper-free Sonogahsira cross-coupling reaction of iodobenzene with phenylacetylene in the presence of potassium hydroxide (KOH) in dimethylsulfoxide (DMSO) at $80{ }^{\circ} \mathrm{C}$, $100{ }^{\circ} \mathrm{C}, 140{ }^{\circ} \mathrm{C}$ with the catalyst loading of $2 \mathrm{mmol} \%$. There was an increase in percent conversion of iodobenzene with temperature, and the percentage yield of the product of the coupling reaction was reported to be in direct proportion with temperature [18]. Table 5 shows that PdLN was a better catalyst than PdLM as the former reached $100 \%$ conversion of iodobenzene at $100{ }^{\circ} \mathrm{C}$ as opposed to $140{ }^{\circ} \mathrm{C}$ for the latter. PdLN had shown a better catalytic performance than the previously reported $[13,19]$ catalysed reaction which reached $100 \%$ conversion at $140{ }^{\circ} \mathrm{C}$. 
Table 5. Percentage of iodobenzene conversion

\begin{tabular}{lccc}
\hline \multirow{2}{*}{ Catalyst } & \multicolumn{3}{c}{ \% Conversion of Iodobenzene } \\
\cline { 2 - 4 } & $\mathbf{8 0}{ }^{\circ} \mathbf{C}$ & $\mathbf{1 0 0}^{\circ} \mathbf{C}$ & $\mathbf{1 4 0}^{\circ} \mathbf{C}$ \\
\hline PdLM & 85 & 66 & 100 \\
PdLN & 85 & 100 & 100 \\
\hline
\end{tabular}

The electron withdrawing group $-\mathrm{NO}_{2}$, seemed to have enhanced the catalytic performance of PdLN more effectively than the electron donating group $-\mathrm{OCH}_{3}$. Ahmad [20] reported the performance of an analogous unsubstituted palladium(II) complex as catalyst, showing $71 \%$ conversion of the iodobenzene, in between that of $\operatorname{PdLM}(66 \%)$ and PdLN $(100 \%)$, at $100{ }^{\circ} \mathrm{C}$. This clearly indicated the significance of the electronic environment of the Schiff base ligands on the catalytic activity of the central Pd(II). As there was no copper co-catalyst used, the undesired formation of the oxidative homocoupling product, a diyne, was not seen in the GC-FID chromatograms.

\section{Conclusion}

Two symmetrical tetradentate Schiff bases bearing $O N N O$ donor atoms and their respective palladium(II) complexes namely PdLM and PdLN were successfully synthesized and characterized through elemental analysis, FTIR, ${ }^{1} \mathrm{H}$ and ${ }^{13} \mathrm{C}$ NMR, magnetic susceptibility and molar conductivity. The spectral data obtained showed that complexation between ligands with palladium(II) was achieved through azomethine nitrogen and phenolic oxygen. Reaction temperature was found to be in direct proportion with the percent conversion of iodobenzene. PdLN, bearing an electron withdrawing $-\mathrm{NO}_{2}$ substituents, showed a higher catalytic activity than PdLM, bearing an electron donating $-\mathrm{OCH}_{3}$ substituents. In future, lower temperature is planned to be applied for homogenous Sonogashira reaction system by having biphasic solvent system i.e. DMSO: $\mathrm{H}_{2} \mathrm{O}$

\section{Acknowledgement}

The authors would like to acknowledge the Ministry of Education, Malaysia and Universiti Teknologi MARA for the support through TPM scholarship, research grant (600-IRMI/PERDANA5/3 BESTARI(046/2018)) and research facilities.

\section{References}

1. Qin, W., Long, S., Panunzio, M. and Biondi, S. (2013). Schiff bases: A short survey on an evergreen chemistry tool. Molecules, 18(10): 12264 - 12289.

2. Abu-Dief, A. M. and Mohamed, I. M. A. (2015). A review on versatile applications of transition metal complexes incorporating Schiff bases. Beni-Suef University Journal of Basic and Applied Sciences, 4(2): 119 133.

3. Jarrahpour, A., Khalili, D., De Clercq, E., Salmi, C. and Brunel, J. M. (2007). Synthesis, antibacterial, antifungal and antiviral activity evaluation of some new bis-Schiff bases of isatin and their derivatives. Molecules, 12(8): 1720 - 1730.

4. Fateh, A., Aliofkhazraei, M. and Rezvanian, A. R. (2017). Review of corrosive environments for copper and its corrosion inhibitors. Arabian Journal of Chemistry. In Press.

5. Gupta, K. C. and Sutar, A. K. (2008). Catalytic activities of Schiff base transition metal complexes. Coordination Chemistry Reviews, 252: 1420 - 1450.

6. Chinchilla, R. and Najera, C. (2011). Recent advances in Sonogashira reactions. Chemical Society Reviews, 40(10): $5084-5121$.

7. Prabhu, R. N. and Pal, S. (2015). Copper-free Sonogashira reactions catalyzed by a palladium(II) complex bearing pyrenealdehyde thiosemicarbazonate under ambient conditions. Tetrahedron Letters, 56(37): 52525256.

8. Siemsen, P., Livingston, R. C. and Diederich, F. (2000). Acetylenic coupling: A powerful tool in molecular construction. Angewandte Chemie International Edition, 39(15): 2632 - 2657. 
9. Bakherad, M., Amin, A. H., Keivanloo, A., Bahramian, B. and Raeissi, M. (2010). Copper-and phosphine-free Sonogashira coupling reactions of aryl iodides catalyzed by an N,N-bis (naphthylideneimino) diethylenetriamine-functionalized polystyrene resin supported $\mathrm{Pd}(\mathrm{II})$ complex under aerobic conditions. Tetrahedron Letters, 51(43): 5653 - 5656.

10. Cozzi, P. G. (2004). Metal-Salen Schiff base complexes in catalysis: Practical aspects. Chemical Society Reviews, 33(7): 410-421.

11. Bakherad, M., Keivanloo, A., Bahramian, B. and Hashemi, M. (2009). Copper-free Sonogashira coupling reactions catalyzed by a water-soluble $\mathrm{Pd}$-salen complex under aerobic conditions. Tetrahedron Letters, 50(14): 1557 - 1559.

12. Das, S. K., Sarmah, M. and Bora, U. (2017). An ambient temperature Sonogashira cross-coupling protocol using 4-aminobenzoic acid as promoter under copper and amine free conditions. Tetrahedron Letters, 58(22): $2094-2097$.

13. He, Y. and Cai, C. (2011). Heterogeneous copper-free Sonogashira coupling reaction catalyzed by a reusable palladium Schiff base complex in water. Journal of Organometallic Chemistry, 696(13): 2689-2692.

14. Pavia, D. L., Lampman, G. M., Kriz, G. S. and Engel, R. G. (2005). Introduction to organic laboratory techniques: a small scale approach. Cengage Learning.

15. Aranha, P. E., dos Santos, M. P., Romera, S. and Dockal, E. R. (2007). Synthesis, characterization, and spectroscopic studies of tetradentate Schiff base chromium (III) complexes. Polyhedron, 26(7): 1373 -1382.

16. Bahron, H., Ahmad, S. N., Tajuddin, A. M. and Kadir, S. I. A. S. A. (2017). Substituent effect on catalytic activity of palladium(II) Schiff base complexes for Sonogashira reaction. Pertanika Journal of Science and Technology, 25: 115 - 124.

17. Amalina, M. T., Hadariah, B., Karimah, K., Wan, N. W. I. and Bohari, M. Y. (2012). Synthesis and characterisation of palladium(II) Schiff base complexes and their catalytic activities for Suzuki coupling reaction. Malaysian Journal of Analytical Sciences, 16(1): 79-87.

18. Rosa, D. S., Antelo, F., Lopes, T. J., Moura, N. F. D. and Rosa, G. R. (2015). Effects of solvent, base, and temperature in the optimisation of a new catalytic system for Sonogashira cross-coupling using NCP pincer palladacycle. Quimica Nova, 38(5): 605 - 608.

19. Guan, J. T., Yu, G. A., Chen, L., Qing Weng, T., Yuan, J. J. and Liu, S. H. (2009). CuI/PPh ${ }_{3}$-catalyzed Sonogashira coupling reaction of aryl iodides with terminal alkynes in water in the absence of palladium. Applied Organometallic Chemistry, 23(2): 75-77.

20. Ahmad, S. N. (2018) Synthesis and characterization of palladium(II) and nickel(II) Schiff base complexes for homogenous catalytic and anticancer studies. Thesis of Doctor Philosophy, Universiti Teknologi MARA. 